\title{
THE IMPORTANCE OF THE QUALITY AND RELIABILITY OF THE HISTORICAL TIME SERIES FOR THE STUDY OF CLIMATE CHANGE
}

\author{
ACQUAOTTA, Fiorella \\ Dipartimento di Scienze della Terra, Università degli Studi di Torino, Via Valperga Caluso, 35 - 10125 \\ Torino, Italy. \\ FRATIANNI, Simona \\ Dipartimento di Scienze della Terra, Università degli Studi di Torino, Via Valperga Caluso, 35 - 10125 \\ Torino, Italy. \\ Centro di Ricerca sui Rischi Naturali in Ambiente Montano e Collinare (NatRisk), Via Leonardo da Vinci \\ 44, 10095 Grugliasco (TO), Italy
}

\begin{abstract}
The value of the datasets employed in climate changes analysis strongly depends on the homogeneity of the time series. In fact, once climate change became an issue of central importance, there arose a much needed skepticism about the results of data analysis work, which frequently indicated sharp or determined changes in regional climates. It is now well recognized that variations in many long term station time series are caused not only by changes in weather and climate, but also by changes in location of the stations, instruments, formulae used to calculate means, observing practices and station environment (Karl and Williams, 1987; Heino, 1994; Gokurk et al., 2008). A homogeneous climate time series is defined as one where variations are caused only by variations in weather and climate (Conrad and Pollak, 1950; Aguilar et al., 2003). Other, unnatural variations are called inhomogenities, which can lead to erroneous interpretations of the studied climate. Thus, before using climatological data in any kind of study - especially in climate change studies - a quality control and homogeneity assessment of data set is mandatory (Peterson et al., 1998). Long instrumental homogeneous records are a basic requirement for evaluating the smooth running of the variables over time and compare the measurement stations and the geographical areas to which they belong. Just to pursue this important objective, a few years ago, between 2007-2012, the European COST Action ES0601 called HOME (Advances in homogenisation methods of climate series) project was devoted to evaluate the performance of homogenization methods used in climatology and produce a software that would be a synthesis of the best aspects of some of the most efficient methods.
\end{abstract}

Keywords.: Climate change, datasets, homogeneity, European COST

A IMPORTÂNCIA DA QUALIDADE E RELIABILIDADE DE SÉRIES HISTÓRICAS PARA O ESTUDO DAS
MUDANÇAS CLIMÁTICAS

RESUMO: O valor dos conjuntos de dados utilizados na análise de mudanças climáticas depende fortemente da homogeneidade da série histórica. Na verdade, uma vez que a mudança climática se tornou uma questão de importância central, surgiu um ceticismo muito necessário sobre os resultados do trabalho de análise de dados, que frequentemente indicam mudanças bruscas ou determinados em climas regionais. Atualmente é bem reconhecido que as variações de longo prazo em séries temporais são causadas não apenas por mudanças do tempo e do clima, mas também por mudanças na localização das estações, instrumentos, fórmulas utilizadas para calcular os meios, observando as práticas e ambiente da estação (Karl e Williams, 1987; Heino, 1994;. Gokurk et al., 2008). Uma série temporal de clima homogêneo é definida como aquela em que as variações são causadas apenas por variações no tempo e do clima (Conrad e Pollak, 1950; Aguilar et al., 2003.). Outras variações não naturais, são chamados de heterogeneas, que podem levar a interpretações errôneas do clima estudado. Assim, antes de usar dados climatológicos em qualquer tipo de estudo - especialmente em estudos de mudança climática - (. Peterson et $a l ;, 1998)$ um controle de qualidade e avaliação da homogeneidade do conjunto de dados é obrigatória. Registros homogêneos instrumentais longos são um requisito básico para a avaliação do bom funcionamento das variáveis ao longo do tempo e comparar as estações de medição e as áreas geográficas a que pertencem. Só para prosseguir este importante objetivo, há alguns anos, entre 2007-2012, a ES0601 Acção COST Europeu chamada HOME (Avanços em métodos de homogeneização de séries climáticas) é projeto foi dedicado a avaliar o desempenho dos métodos de homogeneização utilizados em climatologia e produzir um software que seria uma síntese dos melhores aspectos de alguns dos métodos mais eficientes, objeto deste texto.

Palavras-chave .: mudança climática, conjuntos de dados, homogeneidade, CUSTO Europeia 


\section{INTRODUCTION}

The ever more frequent occurrence of extreme weather events, droughts, heat waves, floods and hurricanes, has meant that the study of the climate and its variations has become very topical in recent years, and has prompted the scientific community to intensify their studies in order to identify changes at a global scale. If the problem is considered purely from the human point of view, it should be pointed out that these changes do not so much threaten the existence of human beings, but rather lead to the potential worsening of the intensity of these changes (IPCC, 2007; IPCC, 2013; Alexander et al., 2006). It is therefore important to try to understand the current climate changes and the intensity of the evolution that is taking place as much as possible in order to try to identify the symptoms or signs of the climate of tomorrow (WMO 2009; Pinna, 1996).

The thorough study of the climate and its variations, however, requires the use of long historical series, reliable and of high quality. In this perspective were born several international projects aimed at promoting recovery and exchange of meteorological and complete series of high quality as MEDARE (MEditerranean climate DAta Rescue, http://www.omm.urv.cat/MEDARE) project, an international initiative, born under the auspice of the World Meteorological Organization, with the main objective is being to develop, consolidate and progress climate data and metadata rescue activities across the Greater Mediterranean Region (GMR). Moreover, the importance of the data has given rise to several international dataset (like ECAD European Climate Assessment and Data, GCOS The Global Climate Observing System or GHCN Global Historical Climatology Network) where many long instrumental climate records are available. These datasets are essential since they are the basis for assessing century-scale trends, for the validation of climate models, as well as detection and attribution of climate change at a regional scale. The value of these datasets, however, strongly depends on the homogeneity of the time series. In fact, once climate change became an issue of central importance, there arose a much needed skepticism about the results of data analysis work, which frequently indicated sharp or determined changes in regional climates. It is now well recognized that variations in many long term station time series are caused not only by changes in weather and climate, but also by changes in location of the stations, instruments, formulae used to calculate means, observing practices and station environment (Karl and Williams, 1987; Heino, 1994; Gokurk et al., 2008). A homogeneous climate time series is defined as one where variations are caused only by variations in weather and climate (Conrad and Pollak, 1950; Aguilar et al., 2003). Other, unnatural variations are called inhomogenities, which can lead to erroneous interpretations of the studied climate. Thus, before using climatological data in any kind of study - especially in climate change studies - a quality control and homogeneity assessment of data set is mandatory (Peterson et al., 1998). Long instrumental homogeneous records are a basic requirement for evaluating the smooth running of the variables over time and compare the measurement stations and the geographical areas to which they belong. Just to pursue this important objective, a few years ago, between 2007-2012, the European COST Action ES0601 called HOME (Advances in homogenisation methods of climate series) project was devoted to evaluate the performance of homogenization methods used in climatology and produce a software that would be a synthesis of the best aspects of some of the most efficient methods. 


\section{2.}

ISSN: 1980-055x (Impressa) 2237-8642 (Eletrônica)

Meteorological (and related environmental and geophysical) observations are made for a variety of reasons. They are used for the real-time preparation of weather analyses, forecasts and severe weather warnings, for the study of climate, for local weather dependent operations (for example, local aerodrome flying operations, construction work on land and at sea), for hydrology and agricultural meteorology, and for research in meteorology and climatology.

The increased use of meteorological data required more continuous and reliable records of climatic variables driving the scientific community to introduce international standards in the installation of meteorological instruments (WMO, 2008, WMO, 1983).

The first and great deal of progress was made in the meteorological field in the Sixteenth and Seventeenth centuries, when instruments allowed objective measurements of atmospheric phenomena. The Accademia del Cimento was set up in this context on 19 June 1657. A group of scientists, began to investigate the atmosphere through the use of a scientific-experimental method, and, for the very first time, they organized an international meteorological network located throughout the European territory (Florence, Vallombrosa, Cutigliano, Bologna, Parma, Milan, Paris, Innsbruck, Osnabruck and Warsaw).

A decisive turning point in the development of meteorological networks occurred round about 1850 , with the creation and enhancement of measurement instruments and the improvement in the communication network between the different locations (due to the invention of the telegraph in 1843). With the installation of the first meteorological observatories, the most important climatic variables (temperature and rainfall) were measured regularly, and a rapid exchange of the recorded data between different countries or different continents was thus possible. At the end of the XIV century, several nations officially established their meteorological services, and international cooperation in meteorology was launched. The International Meteorological Organization was instituted in 1873, and in 1950, was transformed into the present World Meteorological Organization (WMO), with headquarters in Geneva.

The rich meteorological dataset has been collected over the years contains a set of precious information, which, even today, not only allows one to recognize the climatic variations that have occurred in a zone, but also to cast light on the formation mechanisms of the climate, and to makes future forecasts easier. However, the data contained in the archives are not on their own enough to be able to proceed with a detailed reconstruction of the climate. The conditions necessary for this require that a homogeneous data set should be available. Not only the quantity, but also the quality of the original data is able to influence analyses to a remarkable extent; climatic signals can be falsified or altered by anthropic factors, which can occur during the various acquisition and processing phases. The position of a station, the typology of the instruments that are used and the territory all constitute a complex system of factors that can condition the measured values, introducing different discontinuities in the series (Wijngaard et al., 2003).

The inhomogeneities manifest themselves in two principal ways: with a abrupt discontinuity or a gradual trend in the average values. The abrupt variation in the mean values are often caused by change in observational routines, among which are station relocations, changes in instruments and changes in observing practices. Instead the gradual changes may occur due to progressive variations in the environmental conditions (growing of a city or development of vegetation in the area near the station), or by the drift of the instruments. These information 
about the station history are called metadata (data about data) and they have a unique element in common they change the real behaviour of the meteorological variables altering the recording of the variables.

Good metadata are needed to ensure that the final data user has no doubt about the conditions in which data have been recorded, gathered and transmitted, in order to extract accurate conclusions from their analysis. The knowledge of the exact date and time when a instrument was replaced and the technical characteristics of the new and the old instrument, will surely help to remove the non-climatic fingerprint of this change.

The importance and necessity of metadata can also be understood by quoting one of the GCOS Climate monitoring principles: "The details and history of local conditions, instruments, operating procedures, data processing algorithms and other factors pertinent to interpreting data (i.e. metadata) should be documented and treated with the same care as the data themselves" (WMO, 2002).

Unfortunately, metadata are often not complete, missing or sometimes actually erroneous (e.g. when the author of the metadata completes the form from memory several years after the change occurred) so an accurate historical research is necessary to recovery the information. These metadata can be found in station records, meteorological yearbooks (Figure 1), original observation forms, station inspection reports and correspondence, and various technical manuscripts. Metadata can also be acquired from interviews with persons responsible for station operations.

During the historical research, in particular for an ultra secular series it is very important to consider:

- The geographical data: latitude and longitude, the elevation above mean sea level and her relocations focusing on the differences between the diverse positions (Figure 2).

- Observer: it is important to know if the observer is always the same person, or if he/she is different people in particular during the period of manual instruments with a direct reading of the meteorological variable.

- Observed elements: meteorological stations should keep a single list with the current meteorological elements observed/measured directly and those calculated indirectly from the observations at the station.

- Observing times: times and number of observations vary between stations and over the years at a particular station, and these changes can be the cause of a break in the homogeneity of a climate time-series.

- Urbanization and land-use changes: growing population numbers and an increase of buildings associate with a changes in land-use can show an impact on meteorological series.

- Introduction of Automatic Weather Stations or new types of instruments: the replacement of old manual instruments with new automatic instruments alter the recorded of the data by the sensibility and performance of the two instruments (Figure $3)$.

For example, for the Greater Alpine Region a bias in the temperature trend between 1870 s and 1980 s of half a degree was found, which was due to decreasing urbanization of the network and systematic changes in the time of observation (Bohm et al., 2001). The precipitation records of the early instrumental period are biased by $-10 \%$ due to the systematically higher installation of the gauges at the time (Auer et al., 2005). Other possible bias sources are new 
types of weather shelters (Brunet et al., 2011; Brunetti et al., 2006), the change from liquid and glass thermometers to electrical resistance thermometers (Menne et al., 2009), as well as the tendency to replace observers by automatic weather stations (Begert et al., 2005), the much discussed urban heat island effect (Hansen et al., 2001; Peterson 2003) and the transfer of many urban stations to airports (Trewin, 2010).
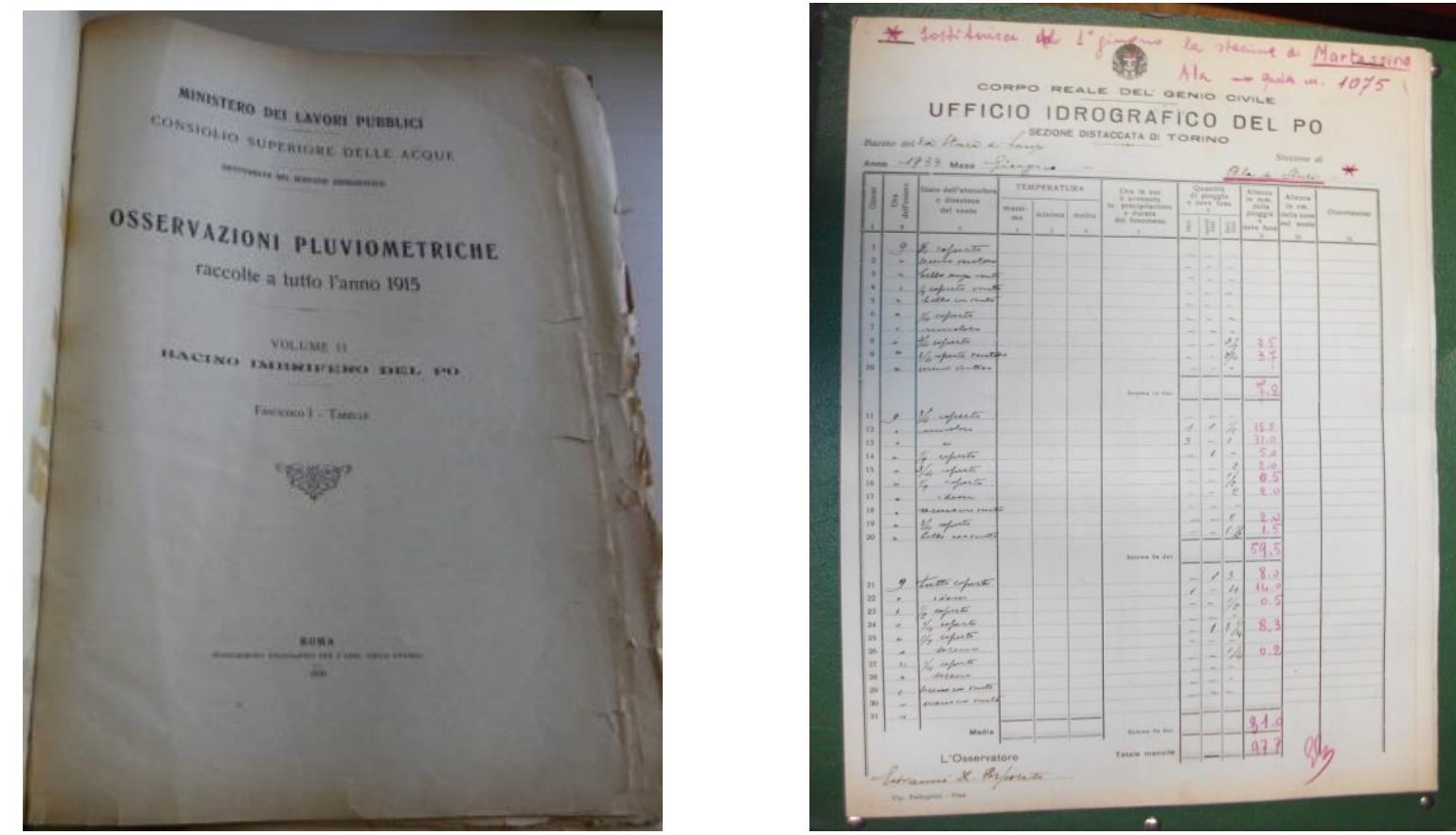

Figure 1: (left) Front page of an italian paper register "Osservazioni pluviometriche raccolte a tutto I'anno 1915, Ministro dei Lavori Pubblici, Consiglio Superiore delle Acque"; (right) An example of meteorological yearbook. In these papers are reported in red the historical informations, metadata, of the station written by the operator. In particularly in this page is indicated a change of the position.
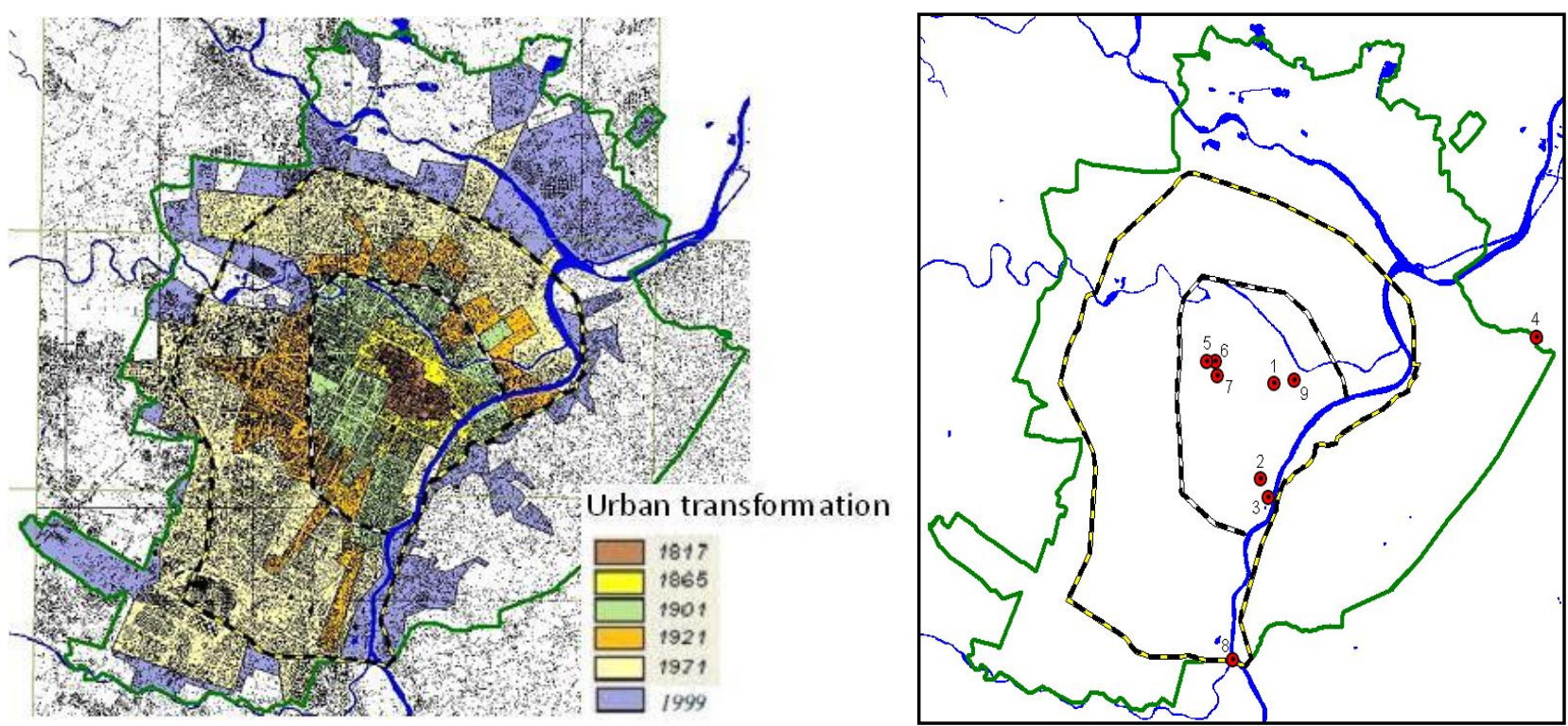

Figure 2: Changes of position of historical series of Turin, Italy, from 1870 to 2013; (left) map of the city, (right) Observatories of the city of Turin (red dots): 1) Palazzo Madama, 2) Institute of Physics, 3) Medieval Castle, 4) Basilica of Superga, 5) UIPO via Gropello, 6) UIPO c.so Inghilterra, 7) UIPO c.so Bolzano, 8) ARPA Vallere, 9) ARPA Royal Garden. Inner dotted line: duty border in 1853; external dotted line: duty border in 1912; gray line: municipal boundaries, black lines: rivers, (Garzena et al., 2012). 


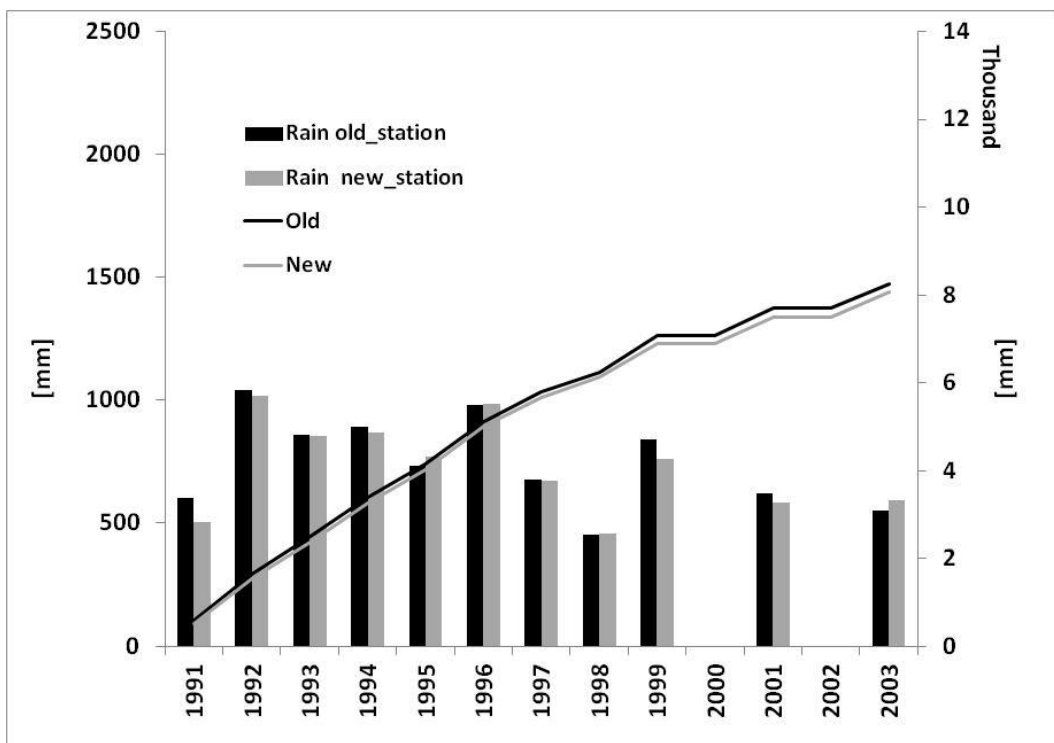

Figure 3: Annual (left axis) and cumulative amount (right axis) of daily precipitation series of Bardonecchia (1250 m asl, NW of Italy) recorded by old station (black) and new station (grey). To resolve the replacement of old manual instruments with new automatic instruments it is necessary to use the parallel measurements. They are very important to be able to maintain them for so long as possible, as they can document the effect of the introduction of the new system in data.

\section{QUALITY CONTROL}

An important step in the data analysis is the quality control (QC) to detect and identify the errors made in the process of recording, manipulating, formatting, transmitting and archiving data.

For the automatic stations a computerized check has been performed on the data and the values have been flagged. The flags are indicated generally with an alphabetic letters or with a numeric values. The flags can indicate values that may be wrong because of missing or suspicious data, aggregation calculated on a percentage of data less than a threshold, aggregation judged not good at time of interactive validation or reconstructed data using neighboring stations, and only one flag indicates the correct values without error or uncertainties in the record phase.

For the manual stations the data have been written in a paper records and, in the most countries, the manuscript forms are sent periodically to a central location. In the paper records notes were made regarding extreme or catastrophic events as high or low temperatures, abnormal wind speeds or excessive rainfall. Despite the heed in the data storage the verification for consistency and arithmetical form of the observed, recorded and collected data was not undertaken. Only in some sporadic case the quality control was made by an interested and responsible individual (WMO, 1983).

On historical series it is necessary that the data be subjected to an accurate quality control before the values are regarded as satisfactory for current use and permanent storage. The quality control applied at every processing stage should form part of the descriptive information contained in a digital data catalogue. The original historical series should be enriched with the flag series to understand the reliability of the data. 
The principal error of the data fall in three categories:

- The instrumental error: missing data or error in format, error of magnitude and error in internal consistency of an observation.

- Errors made by the observer: incorrect reading of the instrument and error in the digitization of the data.

- Errors introduced by the transmission: not transmission of the data.

The principal tools of climate analysis, RClimdex (Zhang et al., 2004), ProClimDB (Stepanek, 2008) and Climatol (Guijarro, 2014), as first steps carry out a quality control. They print out the suspect observations in any one of the given conditions. The user should examine these lists and after an accurate research, using the original manuscript or the neighbouring stations, determine the accuracy of the values. For example RClimdex indicates all unreasonable values. Those values include daily precipitation amounts less than zero and daily maximum temperature less than daily minimum temperature. In addition, QC also identified outliers in daily temperature. The outliers are the daily values outside a region defined by the user [mean - n*std, mean $+n *$ std; std = standard deviation].

Generally the QC is a procedure that combines two way, objective and subjective. The objective method is created by a sequence of mathematical steps that allow to select the suspect values while the subjective method leaves to the users to decide the quality of the data for not to delete the correct values representative of the microclimate.

Particular attention in the analysis of meteorological data should be devoted to the identification of missing data. In particular, the weight that the gap assume in the calculation of climatic variables, monthly, seasonal and annual values. For maximum temperatures a gap in the winter months overestimates the annual value of the variable and a gap in the summer months underestimates the annual value of the variable. The presence of the missing data in the meteorological series is not a problem associated with a particular period or to a specific equipment but it is closely related to the history of the station. The breaking of the equipment or the temporary suspension of recordings due to external causes such as wars, reorganization of the meteorological network or exchange of staff create stranded breaks in the recording of the variable.

The tools of climate analysis consider this problem highlighting as first step the presence of missing data to allow to the users to know the size of the gaps and to assess their influence on the analysis.

The scientific community aware of the presence of gaps in the series has established clear parameters for the calculation of the variables in order to standardize the treatment of the data. The monthly values of precipitation and maximum and minimum temperature are calculated if you have available at least $80 \%$ of daily data (Klein Tank et al., 2002) so that for each month the gap not exceeding 6 non-consecutive days. Also for the season values it is necessary to have at least $80 \%$ of daily data, gap less 18 non-consecutive days. For annual averages, calculated from the daily values, be deemed complete if we have available at least $94 \%$ of the daily data (Klein Tank and Können, 2003), a gap equivalent to 20 not-consecutive days.

It is possible to eliminate the problems caused by missing data with an accurate estimation of missing observations by using the reconstruction methods (Eischeid et al., 2000; Acquaotta et al., 2009). There are numerous methods available for point estimation with irregularly spaced 
data. The Singular Spectrum Analysis (SSA) (Kondrashov and Ghil, 2006), Kalman filtering and optimal smoothing in EOF space (Kaplan et al., 1997), the normal ratio method (NR) (Paulhus and Kohler 1952; Young, 1992), the simple inverse distance weighting (IDW), the optimal interpolation (OI) (Gandin and Kagan, 1974; Reynolds and Smith, 1994) and the method of multiple regression using the least absolute deviations criteria (MLAD) (Barrodale and Roberts, 1973). Typically, the choice of methodology is dependent on several factors: the meteorological variable under consideration, the geographical area, the spatial distribution of surrounding observations, and the day-month-season for which the target station is to be estimated (Schlatter, 1975; Bennet et al., 1984; Thiebaux and Pedder, 1987).

Clearly an inadequate practice can create unrealistic and discontinuous results. More importantly, the arbitrary replacement of missing data values can confound the comparison of solutions based on different modelling approaches (Arthur et al., 1995).

\section{HOMOGENIZATION}

Most long-term climatological time series have been affected by a number of non-climatic factors that make these data unrepresentative of the actual climate variation occurring over time. All of these inhomogeneities can bias a time series and lead to misinterpretations of the studied climate. Numerous studies also indicate that inhomogeneities are not always independent, but can collectively lead to artificial biases in climate trends across large regions (Begert et al., 2005; Brunetti et al., 2006; Menne et al., 2010). Inhomogeneities are thus a significant source of uncertainty for the estimation of secular trends and decadal-scale variability. It is important, therefore, to remove the inhomogeneities or at least determine the possible error they may cause.

Many researchers have put a great deal of effort into developing ways to identify non-climatic inhomogeneities and then adjust the data to compensate for the biases these inhomogeneities produce. Several techniques have been developed to address a variety of factors that impact climate data homogenization such as the type of element (temperature versus precipitation), spatial and temporal variability depending on the part of the world where the stations are located, length and completeness of the data, availability of metadata, and station density.

The most commonly used method to detect and remove the effects of artificial changes is the relative homogenization approach, which assumes that nearby stations are exposed to almost the same climate signal and that thus the differences between nearby stations can be utilized to detect inhomogeneities (Conrad and Pollak, 1950). In relative homogeneity testing, a candidate time series is compared to multiple surrounding stations either in a pairwise fashion or to a single composite reference time series computed for multiple nearby stations.

The method used to form the reference time series is important and need to be tailored specifically to the network and adjustment methodology particularly because the homogeneity of the stations contributing to the reference series can usually not be assessed ahead of time. Therefore the creation of reference series is central to many homogeneity adjustment approaches. Potter (1981) created a reference series using a mean of all the neighbor stations, Alexandersson (1984) developed a technique for creating a reference series by using correlation coefficient between all sites and minimizing the coefficient of variation and finally Peterson and Easterling (1994) created reference series from a network of stations that can change with time by choosing the best stations available for each year because there are times when such data are not good enough. They determined that the correlation ( $r$, of the first 
difference series) between the reference series and the candidate station had to be 0.80 or higher to be reliable enough to use.

The most homogeneous relative test are the Standard Normal Homogeneity Test (SNHT), the Craddock test, the Caussinus-Mestre method and the Multiple Analysis of Series for Homogenization (MASH) (Peterson et al., 1998).

- The Standard Normal Homogeneity Test (SNHT) was developed by Alexandersson (1986) and it is widely used. There are now variations in this test to account for more than one discontinuity, testing for inhomogeneous trends rather than just breaks, and inclusion of change in variance (Alexandersson and Moberg, 1997). The SNHT is a likelihood ratio test and it is performed on a ratio or difference series between the candidate station and a reference series.

- The Craddock test, developed by Craddock (1979), requires a homogeneous reference series. The test accumulates the normalized differences between the test series and the homogeneous reference series. In the final version of the test it is not necessary to have homogeneous reference series but it is sufficient to have long enough homogeneous sub-periods (Boehm, 1992).

- The Caussinus-Mestre method (1996) simultaneously accounts for the detection of an unknown number of multiple breaks and generating reference series. It is based on the premise that between two breaks, a time series is homogeneous and these homogeneous sections can be used as reference series. Each single series is compared to others within the same climatic area by making series of differences (temperature, pressure) or ratio (precipitation). These difference or ratios series are tested for discontinuities. When a detected break remains constant throughout the set of comparisons of a candidate station with its neighbours, the break is attributed to the candidate station time series.

- The Multiple Analysis of Series for Homogenization (MASH), developed by Szentimrey $(1999 ; 2007 ; 2008)$ in the Hungarian Meteorological Service, also does not assume a reference series is homogeneous. Possible break points and shifts can be detected and adjusted through mutual comparisons of series within the same climatic area. The candidate series is chosen from the available time series and the remaining series are considered reference series. The role of the various series changes step by step in the course of the procedure. Depending on the climatic elements, additive or multiplicative models are applied. The multiplicative models can be transformed into additive models by conversion to logarithms.

Therefore, adequate reference series could not be made for many remote stations. In fact, a major problem for the Global Historical Climatology Network, GHCN (Peterson and Vose, 1997) is that station coverage in some parts of the world, such as Africa, varies considerably with time. There are some isolated stations without adequate neighbors where more reliance must be given to the individual station data alone. In these cases it is necessary to use only the data of the candidate station by statistical tests. Zurbenko et al. (1996) describes a filter that has been applied to single station data to date a discontinuity. This process, which is iterative, can smooth out the noise of the time series while retaining discontinuities as distinct breaks. Rhoades and Salinger (1993) have derived a number of statistical procedures for homogenizing isolated station data. Although adjustments for discontinuities are necessarily more subjective, a variety of graphical and analytical techniques were found useful in deciding 
homogeneity adjustments. Recently Wang (2008) proposed a penalized maximal t test for detecting undocumented mean shifts in a single series.

The large number of different monthly homogenization methods and the need for a realistic comparative study was the reason to start a coordinated European initiative, the COST Action HOME ES0601: advances in HOmogenization MEthods of climate series: an integrated approach (HOME). Its main objective was to review and improve common homogenization methods, and to assess their impact on climate time series (HOME, 2011). Based upon a survey among homogenization experts, the Action has chosen to focus on networks with monthly values for temperature and precipitation. Temperature and precipitation were selected because most participants consider these elements as most relevant and, for these two variables, there are available long and well documented series. Furthermore, these elements represent two important types of statistical models (additive and multiplicative).

For a climatologist it is necessary to know to what degree decadal variability and trends in data can be falsified by the inhomogeneities. To be able to answer these questions it is required an evaluation of the output of full homogenization methods on an artificial data with known inhomogeneities randomly inserted (Domonkos, 2008; Domonkos et al., 2011). The inserted inhomogeneities range from simple one-break cases to cases with a very complete and realistic description of the inhomogeneities, including platform-like inhomogeneities in which after the first break there is soon a second break in the opposite direction (Venema et al., 2006a). On this database the homogeneous tests, SNHT, Craddock and RhtestV2, were carry out and then modern techniques were developed focus on methods specifically designed to detect and correct multiple change-points and work with inhomogeneous references (Mestre, 1999; Szentimrey, 1999; Caussinus and Mestre, 2004; Menne and Williams, 2009).

Thank these accurate comparisons and develop of methodologies the COST Action ES0601 HOME produce a software that would be a synthesis of the best aspects of some of the most efficient methods. HOMER (HOMogenizaton softwarE in R) is a software for homogenizing essential climate variables at monthly and annual time scales. HOMER has been constructed exploiting the best characteristics of some other state-of-the-art homogenization methods, i.e., PRODIGE (Caussinus and Mestre, 2004), ACMANT (Domonkos, 2011), CLIMATOL (Guijarro, 2014) and the recently developed joint-segmentation method (cghseg) (Picard et al., 2011). HOMER is based on the methodology of optimal segmentation with dynamic programming, the application of a network-wide two factor model both for detection and correction, and some new techniques in the coordination of detection processes from multi annual to monthly scales. It shall not be considered as an automatic method, since manual input is still required in order to control the homogenization process (Mestre et al., 2013).

HOMER is recommended by the COST Action, without excluding Craddock (1979), MASH (Szentimrey, 2007), USHCN (Menne and Williams, 2005), ACMANT (2011) software that got valuable results during COST benchmark experiments (Venema et al., 2012). Different homogeneity adjustment techniques naturally produce different results. Deciding which technique, variant of a technique, or combination of techniques is best can be difficult and depends on the task and resources available. 


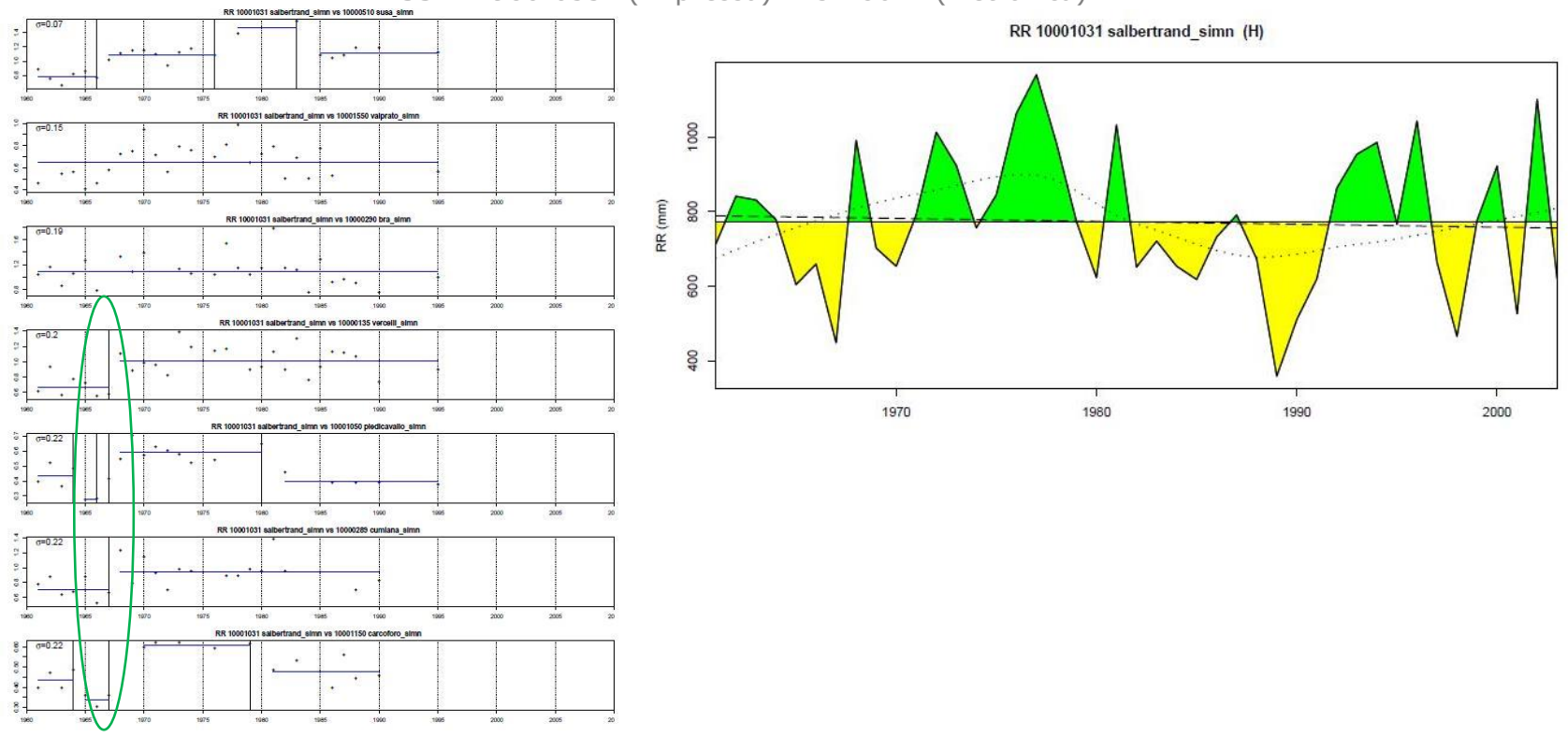

Figure 4: Some graphical elaborations of HOMER on daily precipitation series of Salbertrand (1031 m asl, NW of Italy): left, identification of the inhomogeneity highlighted in green; right, the homogeneous annual amount of precipitation. In green the values higher than the mean value in yellow the values below the mean value. Making proper homogeneity adjustments can be tedious and exacting work, but accounting for the inhomogeneities that climate data often contain is crucial prior to many types of climate analyses. Without proper adjustments, erroneous conclusions may be inevitable in some cases.

The creation of an archive of long-time, reliable and high quality data sets in fact allows to understand, identify, forecast and react to climatic variability and changes, as well as their impact on the fragile socio-economic systems. Variations in the temperature, in the rainfall events and in particularly the typologies of extreme events have in fact been pointed out from the studies conducted by WGI of Intergovernmental Panel on Climate Change (IPCC, 2013). There is a general consensus within the climate community that any change in the frequency or severity of extreme climate events would have profound impacts on nature and society. It is thus very important to analyze extreme events by using the climate indices (Table 1 ).

The joint CCI/CLIVAR/JCOMM Expert Team (ET) on Climate Change Detection Indices (ETCCDI) has addressed the objective measurement and characterization of climate variability and change by providing international coordinating. The ET has coordinated an international efforts to develop, calculate and analyze a suite of indices (27 indices, Table 1). They are based on daily temperature values or daily precipitation amount. Some are based on fixed thresholds that are relevance for particular application. Other indices are based on thresholds that vary from location to location. In these cases, thresholds are typically defined as a percentile of the relevant data series. The suite of indices will allow to the individuals, countries and regions to calculate the variables in exactly the same way such that their analyses will fit seamlessly into the global picture (Karl et al, 1999, Peterson et al., 2001). 
Revista Brasileira de Climatologia

ISSN: 1980-055x (Impressa) 2237-8642 (Eletrônica)

\begin{tabular}{|c|c|c|}
\hline $\begin{array}{c}\underline{\text { ID }} \\
\text { Indicator name }\end{array}$ & Definitions & UNITS \\
\hline $\begin{array}{c}\text { FD0 } \\
\text { Frost days }\end{array}$ & Annual count when $\mathrm{TN}$ (daily minimum $)<0^{\circ} \mathrm{C}$ & Days \\
\hline $\begin{array}{c}\text { SU25 } \\
\text { Summer days }\end{array}$ & Annual count when $\mathrm{TX}($ daily maximum $)>25^{\circ} \mathrm{C}$ & Days \\
\hline $\begin{array}{c}\text { ID0 } \\
\text { Ice days }\end{array}$ & Annual count when $\mathrm{TX}($ daily maximum $)<0^{\circ} \mathrm{C}$ & Days \\
\hline $\begin{array}{c}\text { TR20 } \\
\text { Tropical nights }\end{array}$ & Annual count when $\mathrm{TN}$ (daily minimum $)>20^{\circ} \mathrm{C}$ & Days \\
\hline $\begin{array}{l}\text { GSL } \\
\text { Growing season Length }\end{array}$ & $\begin{array}{l}\text { Annual ( } 1 \text { st Jan to } 31^{\text {st }} \text { Dec in } \mathrm{NH}, 1^{\text {st }} \text { July to } 30^{\text {th }} \text { June in } \mathrm{SH} \text { ) count } \\
\text { between first span of at least } 6 \text { days with } \mathrm{TG}>5^{\circ} \mathrm{C} \text { and first span after } \\
\text { July } 1 \text { (January } 1 \text { in } \mathrm{SH} \text { ) of } 6 \text { days with } \mathrm{TG}<5^{\circ} \mathrm{C}\end{array}$ & Days \\
\hline $\begin{array}{c}\text { TXx } \\
\text { Max Tmax }\end{array}$ & Monthly maximum value of daily maximum temp & ${ }^{\circ} \mathrm{C}$ \\
\hline $\begin{array}{c}\text { TNx } \\
\text { Max Tmin }\end{array}$ & Monthly maximum value of daily minimum temp & ${ }^{\circ} \mathrm{C}$ \\
\hline $\begin{array}{c}\text { TXn } \\
\text { Min Tmax }\end{array}$ & Monthly minimum value of daily maximum temp & ${ }^{\circ} \mathrm{C}$ \\
\hline $\begin{array}{c}\text { TNn } \\
\text { Min Tmin }\end{array}$ & Monthly minimum value of daily minimum temp & ${ }^{\circ} \mathrm{C}$ \\
\hline $\begin{array}{c}\text { TN10p } \\
\text { Cool nights }\end{array}$ & Percentage of days when $\mathrm{TN}<10$ th percentile & Days \\
\hline $\begin{array}{l}\text { TX10p } \\
\text { Cool days }\end{array}$ & Percentage of days when $\mathrm{TX}<10$ th percentile & Days \\
\hline $\begin{array}{c}\text { TN90p } \\
\text { Warm nights }\end{array}$ & Percentage of days when $T N>90$ th percentile & Days \\
\hline $\begin{array}{c}\text { TX90p } \\
\text { Warm days }\end{array}$ & Percentage of days when $T X>90$ th percentile & Days \\
\hline $\begin{array}{c}\text { WSDI } \\
\text { Warm spell duration indicator }\end{array}$ & $\begin{array}{l}\text { Annual count of days with at least } 6 \text { consecutive days when TX>90th } \\
\text { percentile }\end{array}$ & Days \\
\hline $\begin{array}{c}\text { CSDI } \\
\text { Cold spell duration indicator }\end{array}$ & $\begin{array}{c}\text { Annual count of days with at least } 6 \text { consecutive days when } \mathrm{TN}<10 \text { th } \\
\text { percentile }\end{array}$ & Days \\
\hline $\begin{array}{c}\text { DTR } \\
\text { Diurnal temperature range }\end{array}$ & Monthly mean difference between TX and TN & ${ }^{\circ} \mathrm{C}$ \\
\hline $\begin{array}{c}\text { RX1day } \\
\text { Max 1-day precipitation amount }\end{array}$ & Monthly maximum 1-day precipitation & $\mathrm{Mm}$ \\
\hline $\begin{array}{c}\text { Rx5day } \\
\text { Max 5-day precipitation amount }\end{array}$ & Monthly maximum consecutive 5 -day precipitation & $\mathrm{Mm}$ \\
\hline $\begin{array}{c}\text { SDII } \\
\text { Simple daily intensity index }\end{array}$ & $\begin{array}{l}\text { Annual total precipitation divided by the number of wet days (defined as } \\
\qquad \mathrm{PRCP}>=1.0 \mathrm{~mm} \text { ) in the year }\end{array}$ & Mm/day \\
\hline $\begin{array}{c}\text { R10 } \\
\begin{array}{c}\text { Number of heavy precipitation } \\
\text { days }\end{array}\end{array}$ & Annual count of days when PRCP $>=10 \mathrm{~mm}$ & Days \\
\hline $\begin{array}{c}\text { R20 } \\
\text { Number of very heavy } \\
\text { precipitation days }\end{array}$ & Annual count of days when PRCP $>=20 \mathrm{~mm}$ & Days \\
\hline $\begin{array}{c}\text { Rnn } \\
\text { Number of days above } \mathrm{nn} \mathrm{mm}\end{array}$ & Annual count of days when $\mathrm{PRCP}>=\mathrm{nn} \mathrm{mm}, \mathrm{nn}$ is user defined threshold & Days \\
\hline $\begin{array}{c}\text { CDD } \\
\text { Consecutive dry days }\end{array}$ & Maximum number of consecutive days with $\mathrm{RR}<1 \mathrm{~mm}$ & Days \\
\hline $\begin{array}{c}\text { CWD } \\
\text { Consecutive wet days }\end{array}$ & Maximum number of consecutive days with $\mathrm{RR}>=1 \mathrm{~mm}$ & Days \\
\hline $\begin{array}{c}\text { R95p } \\
\text { Very wet days }\end{array}$ & Annual total PRCP when $R R>95^{\text {th }}$ percentile & $\mathrm{Mm}$ \\
\hline $\begin{array}{c}\text { R99p } \\
\text { Extremely wet days }\end{array}$ & Annual total PRCP when $R R>99^{\text {th }}$ percentile & $\mathrm{mm}$ \\
\hline $\begin{array}{l}\text { PRCPTOT } \\
\text { Annual total wet-day } \\
\text { precipitation }\end{array}$ & Annual total PRCP in wet days $(\mathrm{RR}>=1 \mathrm{~mm})$ & $\mathrm{mm}$ \\
\hline
\end{tabular}


Table 1: Climate Change Indices: definitions of the 27 core indices of the working group ETCCDI.

Although daily dataset have become a focus of climate research, long observational daily meteorological records are affected by inhomogeneities. Looking at the known physical cause of these inhomogeneities, one may expect that the tails of the distribution are especially affected but, in the tails, the extreme events reside. This is a problem because the question to which extent daily homogenization methods can reduce those effects in insufficiently study. In the recent years some daily homogeneous tests have been created, SPLIDHOM (Mestre et al., 2011), GAHMDI (Toreti et al., 2012), Trewin (2013) and Rienzner and Gandolfi (2013) but most available methods are focused on temperature only. The homogenization of daily data and development of better methods should have a high research priority. This research would be much facilitated by a global reference database with parallel measurements.

\section{CONCLUSIONS}

The main research impetus in the last years has been the development of homogenization algorithms that also function with an inhomogeneous reference time series. This effort has paid off. There is a clear split in performance on the dataset between direct algorithms and the ones, which evade the inhomogeneous reference problem using older concepts such as stepwise or semi-hierarchical splitting, as well as detection on moving windows. With mathematical argumentation, climatological reasoning and the benchmark metrics all pointing in the same direction, the COST Action members strongly recommend the use of direct homogenization algorithms.

Anyway, it is important to preserve the original data as well as homogeneity-adjusted versions. Also, original data need to be preserved because new and better approaches to homogeneity adjustments will probably be developed in the near future. During the last decade, considerable work has been done on homogeneity testing and data adjustments and research will continue in this field. Future work includes improving adjustment methodologies, investigating adjustments of daily data, and evaluating the impact of adjustments on extreme values. With continuing efforts to put current climate variability, change, and extreme events into historical perspective, the need for reliable, homogeneous climate data sets will increase.

In fact, the rich collection of homogeneous weather data is still largely unexplored, despite past efforts in the accurate monitoring of the atmosphere carried out across the world and the current urgent need to develop long term reliable and high quality climatic time series, in order to better understand, detect, predict and react to global climate variability and change.

Data produced from meteorological and climatological networks represent a valuable and often unique resource, acquired with substantial expenditure of time, money and effort. Many of the ultimate uses for climate data cannot be foreseen when the data acquisition projects are being planned, and frequently new applications emerge, long after the information is acquired. The analysis of the datasets do not have only an immense scientific value, they also offer political, social and economic advantages, and they are required in order to:

Contribute to the advancement in the identification and understanding of climate change. The recovering of the large amount of historical daily meteorological data recorded over the world and belonging to several Institutions is of considerable interest, given the high historical and climatological value of these daily data existing only on paper archives.

Predict extreme events in the long run allowing, for example, to determine more accurately the return period. The availability of reliable and long term daily time series will allow to perform the analysis of the extreme events of the considered parameters, i.e. the severe events with the strongest impact on the society in terms of mobility and damages to structures. Frequency and intensity trends will be evaluated as it has been documented that even a small change in climatic conditions may cause a major change in the frequency of extreme events. For example, these data have been used to 
determine where to build homes by calculating the return periods of large floods, whether the length of the frost-free growing season in a region is increasing or decreasing, and the potential variability in demand for heating fuels. However, for these and other long-term climate analyses - particularly climate change analyses - to be accurate, the climate data used must be as homogeneous as possible.

Development of climate change scenarios combining measured data with simulation from Regional Climate Models. The comparison between models and observation permit to validate the models and to correct the future scenario data, with post-processing and down-scaling techniques like quantile mapping, multi-model technique, analogue method, weather generator.

Calibrate satellite estimates of surface variables. The availability of large scale reliable and consistent spatial data as those of the MODIS Terra and Aqua dataset allows to evaluate the space-time variability of the temperature, precipitation and snow cover extent and provide essential information not only for climatology, but also for several applications in hydrology and in the study of the ecosystems adaptation to climate change.

\section{REFERENCES}

Acquaotta F., Fratianni S., Cassardo C. and Cremonini R.: On the continuity and climatic variability of the meteorological stations in Torino, Asti, Vercelli and Oropa. Meteorology and Atmospheric Physics, 103: 279-287, doi: 10.1007/s00703-008-0333-4, 2009.

Aguilar E., Auer I., Brunet M., Peterson T. C., and Wieringa, J.: Guidelines on climate metadata and homogenization. World Meteorological Organization, WMO-TD No. 1186, WCDMP No. 53, Geneva, Switzerland, p 55, 2003.

Alexandersson H.: A Homogeneity Test Based on Ratios and Applied to Precipitation Series. Report 79, Department of Meteorology, Uppsala, p 55, 1984.

Alexandersson H.: A homogeneity test applied to precipitation data. J. Climate, 6: 661-675, 1986.

Alexandersson $H$. and Moberg A.: Homogenization of Swedish temperature data.1, Homogeneity test for linear trends. Int. J. Climatol., 17: 25-34, 1997.

Alexander L. V., Zhang X., Peterson T. C., Caesar J., Gleason B., Klein Tank A. M. G., Haylock M., Collins D., Trewin B., Rahimzadeh F., Tagipour A., Rupa Kumar K., Revadekar J., Griffiths G., Vincent L., Stephenson D. B., Burn J., Aguilar E., Brunet M., Taylor M., New M., Zhai P., Rusticucci M. and Vazquez-Aguirre J. L.: Global observed changes in daily climate extremes of temperature and precipitation. Journal of Geophysical Research: Atmospheres, 111, Issue D5, DOI: 10.1029/2005JD006290, 2006.

Auer I., Bohm R., Jurkovic A., Orlik A., Potzmann R., Schoner W., Ungersbock M., Brunetti M., Nanni T., Maugeri M., Briffa K., Jones P., Efthymiadis D., Mestre O., Moisselin J.-M., Begert M., Brazdil R., Bochnicek O., Cegnar T., Gajic-Capka M., Zaninovic K., Majstorovicp Z., Szalai S., Szentimrey T. and Mercalli L.: A new instrumental precipitation dataset for the Greater Alpine Region for the period 1800-2002. Int. J. Climatol., 25: 139-166, 2005.

Barrodale I. and Roberts F. D. K.: An improved algorithm for discrete L1 approximation. SIAM J. Numer. Anal., 10: 839-848, 1973. 
Begert M., Schlegel T., and Kirchhofer W.: Homogeneous temperature and precipitation series of Switzerland from 1864 to 2000. Int. J. Climatol., 25: 65-80, 2005.

Bennet R. J., R. P. Haining and Griffith D. A.: The problem of missing data on spatial surfaces. Ann. Assoc. Amer. Geogr., 74: 138-156, 1984.

Boehm R.: Description of the Procedure of Homogenizing Temperature Time Series in Austria. Centr. Europ. research. Initiative, Proj. Gr. Meteorology, Wp. 2, Vienna, 1992.

Bohm R., Auer I., Brunetti M., Maugeri M., Nanni T. and Schoner W.: Regional temperature variability in the European Alps 1760-1998 from homogenized instrumental time series. Int. J. Climatol., 21: 1779-1801, 2001.

Brunet $M$. and Jones P.: Data rescue initiatives: bringing historical climate data into the 21st century. Clim. Res., 47: 29-40, 2011.

Brunet M., Asin J., Sigro J., Banon M., Garcia F., Aguilar E., Esteban Palenzuela J., Peterson T. C. and Jones P.: The minimization of the screen bias from ancient Western Mediterranean air temperature records: an exploratory statistical analysis. Int. J. Climatol., 31: 1879-1895, 2011.

Brunetti M., Maugeri M., Monti F. and Nanni T.: Temperature and precipitation variability in Italy in the last two centuries from homogenized instrumental time series. Int. J. Climatol., 26: 345-381, 2006.

Caussinus $H$. and Mestre $O$.: New mathematical tools and methodologies for relative homogeneity testing. Proceedings of the Seminar for Homogenization of Surface Climatological Data, Budapest, 6-12 October, 63-82, 1996.

Caussinus H. and Mestre O.: Detection and correction of artificial shifts in climate series. Appl. Statist., 53: 405-425, 2004.

Conrad V. and Pollak C.: Methods in climatology, Harvard University Press, Cambridge, MA, p 459, 1950.

Craddock J. M.: Methods of comparing annual rainfall records for climatic purposes. Weather, 34: 332-346, 1979.

DeGaetano A. T., Eggleston K. L., and Knapp W. W.: A Method to Estimate Missing Daily Maximum and Minimum Temperature Observations. J. Appl. Meteor., 34: 371-380, 1995.

Domonkos P.: Testing of homogenisation methods: purposes, tools and problems of implementation. Proceedings of the 5th Seminar and Quality Control in Climatological Databases, WCDMPNo. 71, WMO/TD-NO. 1493: 126-145, 2008.

Domonkos P.: Efficiency evaluation for detecting inhomogeneities by objective homogenization methods. Theor. Appl. Climatol., 105: 455-467, doi:10.1007/s00704-011-0399-7, $2011 \mathrm{a}$.

Domonkos P.: Adapted Caussinus-Mestre Algorithm for homogenizing Networks of Temperature series (ACMANT). Int. J. Geosci., 2: 293-309, doi:10.4236/ijg.2011.23032, 2011b.

Domonkos P., Poza R. and Efthymiadis D.: Newest developments of ACMANT. Adv. Sci. Res., 6: 7-11, doi:10.5194/asr-6-7-2011, 2011. 
Eischeid J. K., Pasteris P. A., Diaz H. F., Plantico M. S. and Lott N. J.: Creating a Serially Complete, National Daily Time Series of Temperature and Precipitation for the Western United States. Journal of Applied Meteorology, 39: 1580-1591, 2000.

Gandin L. S. and Kagan R. L.: Construction of the system of heterogeneous data objective analysis based on the method of optimal interpolation and optimal agreement (in Russian). Meteor. Gidrol., 5: 3-10, 1974.

Garzena D., Fratianni S., Acquaotta F. and Zavattini J. A.: Analyse de la série climatique de Turinde 1870 à 2010 et considérations sur l'ilot de chaleur urbain. Actes du $\mathbf{X X V}^{\mathbf{e}}$ Colloque de I'Association Internationale de Climatologie, pp 327-332, ISBN 978-2-907696-18-0, 2012.

Göktürk O. M., Bozkurt D., Şen O. L. and Karaca M.: Quality control and homogeneity of Turkish precipitation data. Hydrological Processes, 22 (16): 3210-3218, DOI: 10.1002/hyp.6915, 2008.

Guijarro J. A.: User's guide to climatol. An R contributed package for homogenization of climatological series. Report, State Meteorological Agency, Balearic Islands Office, Spain, available at: http://webs.ono.com/climatol/climatol.html, 2014.

Hansen J., Ruedy R., Sato M., Imhoff M., Lawrence W., Easterling D. R., Peterson T. C. and Karl T. R.: A closer look at United States and global surface temperature change. J. Geophys. Res., 106: 23947-23963, 2001.

Heino R.: Climate in Finland during the period of meteorological observations. Finnish Meteorological Institute Contributions, 12, p 209, 1994.

IPCC: Climate Change 2007: The physical science basis. Contribution of Working Group I to the Fourth Assessment Report of the Intergovernmental Panel on Climate Change, edited by: Solomon S., Qin D., Manning M., Chen Z., Marquis M., Averyt K. B., Tignor M., and Miller H. L., Cambridge University Press, Cambridge, United Kingdom, p 996, 2007.

IPCC: Climate Change 2013: The physical science basis. Contribution of Working Group I to the Fifth Assessment Report of the Intergovernmental Panel on Climate Change, edited by: Stocker T., Quin D., Plattner G., Tignor M., Allen S., Boschung J., Naules A., Xia Y., Bex V. and Midgley P. Cambridge University Press, Cambridge, United Kingdom, p 1535, 2013.

Kaplan A., Kushinir Y., Cane M. and Benno Blumenthal M.: Reduced space optimal analysis for historical data sets: 136 years of Atlantic sea surface temperatures, Journal of Geophysical Research, 102: 27835-27860, 1997.

Karl T. R. and Williams C.: An Approach to Adjusting Climatological Time Series for Discontinuous Inhomogeneities. J. Climate Appl. Meteor., 26: 1744-1763, 1987.

Karl T.R., Nicholls N., and Ghazi A.: CLIVAR/GCOS/WMO workshop on indices and indicators for climate extremes: Workshop summary. Climatic Change, 42: 3-7, 1999.

Klein Tank A. M. G., Wijngaard J. B., Können G. P., Böhm R., Demarée G., Gocheva A., Mileta M., Pashiardis S., Hejkrlik L., Kern-Hansen C., Heino R., Bessemoulin P., Müller-Westermeier G., Tzanakou M., Szalai S., Pálsdóttir T., Fitzgerald D., Rubin S., Capaldo M., Maugeri M., Leitass A., Bukantis A., Aberfeld R., Van Engelen A. F. V., Forland E., Mietus M., Coelho F., Mares C., Razuvaev V., Nieplova E., T. Cegnar, Antonio López J., Dahlström B., Moberg A., Kirchhofer W., Ceylan A., Pachaliuk O., Alexander L. V. and Petrovic P.: Daily dataset of 20THcentury surface air temperature and precipitation series for the European Climate Assessment.

Int. J. Climatol., 22: 1441-1453, 2002. 
Klein Tank A. M. G. and Konnen G. P.: Trends in indices of daily temperature and precipitation extremes in Europe, 1946-1999. Journal of Climate, 16: 3665-3680, 2003.

Kondrashov D. and Ghil M.: Spatial-temporal filling of missing points in geophysical data set. Nonlinear Processes Geophysics, 13: 151-159, 2006.

Menne, M. J., Williams, C. N. Jr., and Vose, R. S.: The U.S. historical climatology network monthly temperature data, version 2, B. Am. Meteorol. Soc., 90: 993-1007, doi:10.1175/2008BAMS2613.1, 2009.

Menne, M. J., Williams, C. N. Jr., and Palecki M. A.: On the reliability of the US surface temperature record. J. Geophys. Res. Atmos., 115, D11108, doi:10.1029/2009JD013094, 2010.

Mestre, O.: Step-by-step procedures for choosing a model with change-points. In Proceedings of the second seminar for homogenization of surface climatological data. Budapest, Hungary, WCDMP-No.41, WMO-TD No. 962, 15-26, 1999.

Mestre, O., Gruber C., Prieur C., Caussinus H., and Jourdain S.: SPLIDHOM: A Method for Homogenization of Daily Temperature Observations. J. Appl. Meteor. Climatol., 50: 23432358, DOI: 10.1175/2011JAMC2641.1, 2011.

Mestre O., Domonkos P., Picard F., Auer I., Stéphane R., Lebarbier E., Böhm R., Aguilar E., Guijarro J., Vertachnik G., Klancar M., Dubuisson B. and Stepanek P.: HOMER: a homogenization software - methods and applications. Quarterly Journal of the Hungarian Meteorological Service, 117(1): 47-67, 2013.

Paulhus J. L. H. and Kohler M. A.: Interpolation of missing precipitation records. Mon. Wea. Rev., 80: 129-133, 1952.

Peterson T.C. and Easterling D.R.: Creation of homogeneous composite climatological reference series. Int. J. Climatol., 14: 671-679, 1994.

Peterson T.C. and Vose R.S.: An overview of the Global Historical Climatology Network temperature data base. Bull. Amer. Meteorol. Soc., 78: 2837-2849, 1997.

Peterson T.C., Easterling D.R., Karl T.R., Groisman P., Nicholls N., Plummer N., Torok S., Auer I., Böhm R., Gullett D., Vincent L., Heino R., Tuomenvirta H., Mestre O., Szentimrey T., Salinger J., Førland E.J., Hanssen-Bauer I., Alexandersson H., Jones P. and Parker D.: Homogeneity adjustments of in situ atmospheric climate data: a review. Int. J. Climatol., 18: 1493-1517, 1998.

Peterson T.C., Folland C., Gruza G., Hogg W., Mokssit A. and Plummer N.: Report on the Activities of the Working Group on Climate Change Detection and Related Rapporteurs 1998-2001. WMO, Rep. WCDMP-47, WMO-TD 1071, Geneve, Switzerland, p $143,2001$.

Peterson T. C.: Assessment of urban versus rural in situ surface temperatures in the contiguous United States: No difference found. J. Climate, 16: 2941-2959, 2003.

Picard F., Lebarbier E., Hoebeke M., Rigaill G., Thiam B. and Robin S.: Joint segmentation, calling and normalization of multiple CGH profiles. Biostatistics, 12: 413-428, 2011.

Pinna M.: Le variazioni del clima, dall'ultima grande glaciazione alle prospettive per il XXI secolo. Edited by: Franco Angeli s.r.l., Milano, Italy, p 214, 1996. 
Potter K.W.: Illustration of a new test for detecting a shift in mean in precipitation series. Mon. Wea. Re6., 109: 2040-2045, 1981.

Reynolds R: and Smith T.: Improved global sea surface temperature analysis using optimal interpolation. Journal of Climate, 7: 929-948, 1994.

Rhoades D.A., and Salinger M.J.: Adjustment of temperature and rainfall records for site changes. Int. J. Climatol., 13: 899-913, 1993.

Rienzner M. and Gandolfi C.: A procedure for the detection of undocumented multiple abrupt changes in the mean value of daily temperature time series of a regional network. International Journal of Climatology 33 (5): 1107-1120, DOI: 10.1002/joc.3496, 2013.

Schlatter T.W.: Some experiments with a multivariate objective analysis scheme. Mon. Wea. Rev., 103: 246-257, 1975.

Stepanek P.: ProClimDB - software for processing climatological datasets. CHMI, regional office Brno, http://www.climahom.eu/ProcData.html, 2008.

Szentimrey T.: Multiple Analysis of Series for homogenization (MASH). Proceedings of the second seminar for homogenization of surface climatological data, Budapest, Hungary, WMO, WCDMP-No. 41, 27-46, 1999.

Szentimrey T.: Manual of homogenization software MASHv3.02. Hungarian Meteorological Service, p 65, 2007.

Szentimrey T.: Development of MASH homogenization procedure for daily data. Proceedings of the fifth seminar for homogenization and quality control in climatological databases, Budapest, Hungary, 2006, WCDMP-No. 71: 123-130, 2008.

Young, K. C.: A three-way model for interpolating monthly precipitation values. Mon. Wea. Rev., 120: 2561-2569, 1992.

Thiebaux H. J., and Pedder M. A.: Spatial Objective Analysis with Applications in Atmospheric Science. Academic Press, p 299, 1987.

Toreti A., Kuglitsch F. G., Xoplaki E., and Luterbacher J.: A Novel Approach for the Detection of Inhomogeneities Affecting Climate Time Series. J. Appl. Meteor. Climatol., 51: 317-326, DOI: http://dx.doi.org/10.1175/JAMC-D-10-05033.1, 2012.

Trewin B.: Exposure, instrumentation, and observing practice effects on land temperature measurements, WIREs Clim. Change, 1: 490-506, DOI:10.1002/wcc.46, 2010.

Trewin B.: A daily homogenized temperature data set for Australia. International Journal of Climatology, 33 (6): 1510-1529, DOI: 10.1002/joc.3530, 2013.

Venema V. K. C., Bachner S., Rust. H.W. and Simmer C.: Statistical characteristics of surrogate data based on geophysical measurements. Nonlin. Proc. Geophys., 13: 449466, 2006.

Venema V. K. C., Mestre O., Aguilar E., Auer I., Guijarro J. A., Domonkos P., Vertacnik G., Szentimrey T., Stepanek P., Zahradnicek P., Viarre J., Muller-Westermeier G., Lakatos M., Williams C. N., Menne M., Lindau R., Rasol D., Rustemeier E., Kolokythas K., Marinova T., Andresen L., Acquaotta F., Fratianni S., Cheval S., Klancar M., Brunetti M., Gruber C., Prohom Duran M., Likso T., Esteban P. and Brandsma T.: Description of the COST-HOME monthly benchmark dataset and the submitted homogenized contributions. Benchmarking 
homogenization algorithms foe monthly data. Climate of the Past, 8: 89-115, DOI: 10.5194/cp-8-89-2012, 2012.

Wang X. L. L.: Accounting for autocorrelation in detecting meanshifts in climate data series using the penalized maximal t or F test. J. Appl. Meteor. Climatol., 47: 2423-2444, 2008.

Wijngaard J. B., Klein Tank A. M. G. and Können G. P.: Homogeneity of 20th century European daily temperature and precipitation series. International Journal of Climatology, 22 (12): 1441-1453, DOI: 10.1002/joc.906, 2003.

WMO: Guide to climatological practices. WMO-No 100, p 198, 1983.

WMO: WMO Technical Document 1125. GCOS-76, 2002.

WMO: Guide to meteorological instruments and methods of observation. WMO-8 81 681, 2008.

WMO: Guidelines on Analysis of extremes in a changing climate in support of informed decisions for adaptation. Climate Data and Monitoring WCDMP-No. 72, p 56, 2009.

Zhang X. and Yang F.: RClimDex(1.0). Software, 2004.

Zurbenko I, Porter P.S., Rao S.T., Ku J.Y., Gui R. and Eskridge R.E.: Detecting discontinuities in time series of upper air data: Development and demonstration of an adaptive filter technique. J. Climate, 9: 3548-3560, 1996. 